\title{
PERAN ETHNOMATEMATIKA DALAM PENERAPAN PEMBELAJARAN MATEMATIKA PADA KURIKULUM 2013
}

\author{
Rino Richardo \\ Prodi Pendidikan Matematika Universitas Alma Ata Yogyakarta \\ Email : rinorichardo@almaata.ac.id
}

\begin{abstract}
The purpose of this study was to describe the ethnomatmatika role in the application of mathematics in the curriculum of 2013. The method used in this research is the study of literature study (library research). The data is collected and analyzed secondary data such as the results of the research as a scientific reading books, scientific journals, research reports, websites and other relevant. Data analysis techniques in the study includes three stages, first, organize, synthesize and identify.

The results showed that: (1) ethnomatematika facilitate learners to be able to construct a mathematical concept with the prior knowledge that they already know because through the environment the students themselves, (2) Ethnomatematika provide a learning environment that creates a good motivation and fun as well as free of the notion that mathematics it's scary, (3) Ethnomatematika able to provide an affective competencies in the form of a sense of respect, nationalism and pride in the heritage of tradition, art and culture of the nation and (4) Ethnomatematika support the capabilities of students to the expectations of the implementation of the scientific approach.
\end{abstract}

Keywords : Ethnomatematika, Curriculum 2013, Mathematicics Learning

\section{PENDAHULUAN}

Salah satu isu yang melatarbelakangi terbentuknya kurikulum 2013 sebagai penyempurnaan dari Kurikulum Tingkat Satuan Pendidikan (KTSP) yakni adanya tuntutan bahwa pembelajaran matematika disekolah harus memafasilitasi siswa untuk aktif, kreatif, dan berpikir kritis. Hal ini dikarenakan berdasarkan hasil survei yang dilakukan oleh lembaga-lembaga internasional seperti Trend in International Mathematics and Science Study (TIMSS) dan Program for International Student Assessment (PISA) yang masih menempatkan peserta didik Indonesia dalam zona bawah. Selain itu, Kementerian Pendidikan dan Kebudayaan (Kemendikbud) menjelaskan bahwa pada tahun 2010-2035 bagi Indonesia dalam mempersiapkan generasi emas karena jumlah penduduk dengan usia sekolah sangat tinggi ${ }^{1}$. Dengan demikian, kebutuhan perubahan kurikulum menuju pembelajaran matematika yang menekankan pada kemampuan

${ }^{1}$ Alawiyah, F, "Kesiapan Guru Dalam Implementasi Kurikulum 2013”, dalam Jurnal Pengkajian (P3D1), Vol. 6, No.15, 2013, hal 9-12 kreatif dan kritis merupakan suatu keniscayaan. Tidak bisa dipungkiri, ketika peserta didik sejak awal dari pendidikan dasar difasilitasi untuk mengembangkan kemampuan berpikir kritis, logis, kreatif, kemampuan bekerjasama maka kemampuan tersebut akan memberikan implikasi yang positif dalam kehidupannya kedepan. Sehingga dengan kemampuan tersebut diharapkan peserta didik dapat bertahan hidup pada kondisi yang selalu berubah, tidak pasti dan kompetitif².

Kurikulum 2013 merupakan kurikulum yang menekankan pembelajaran secara interaktif, inspiratif, menyenangkan, menantang, memotivasi peserta didik untuk berpartisipasi aktif, serta memberikan ruang yang cukup bagi prakarsa, kreativitas, dan kemandirian sesuai dengan bakat, minat, dan perkembangan fisik serta psikologis peserta didik sesuai dengan yang tersurat didalam standar proses. Dalam pembelajaran matematika,

${ }^{2}$ Rahayu, dkk. Pengembangan Instrumen Penilaian Dalam Pendidikan Matematika Realistik Indonesia (PMRI) Di SMPN 17 Palembang. Jurnal Pendidikan Matematika. Vol. 2, No.2, 2008, Hal 19-35. 
umumnya masih banyak dijumpai proses pembelajaran yang konvensional sehingga tidak terlihat keaktifan peserta didik, menjenuhkan, dan tidak memberikan kebermaknaan dan pengalaman yang konkrit dari pembelajaran yang dilalui. Oleh karena itu, sangat dibutuhkan Model/Metode dan pendekatan yang inovatif untuk merealisasikan proses pembelajaran tersebut.

Ada beberapa pendekatan pembelajaran dalam pembelajaran matematika yang tepat atau cocok diterapkan dalam kurikulum 2013. Pendekatan tersebut diantaranya pembelajaran dengan pendekatan ilmiah, Pendekatan pembelajaran kontekstual, Pendekatan pembelajaran berbasis masalah, Pendekatan pembelajaran berbasis Proyek, Pendekatan pembelajaran kooperatif, dan Pendekatan pembelajaran komunikatif ${ }^{3}$. Selain itu, pada kurikulum 2013 mengharapkan adanya kebermaknaan dari materi yang disampaikan sehingga mampu menyentuh aspek dalam kehidupan sehari-hari siswa. Kebermaknaan ini diperoleh karena materi matematika dihubungkan dengan pengalaman siswa, kehidupan sosial, bahkan menyentuh ranah seni dan budaya setempat.

Ketika kita ambil salah satunya, misalnya ranah sosial dan budaya maka kita akan hubungkan bagaimana budaya setempat dapat dikaitkan dengan konsep matematika atau dijadikan sebagai media pembelajaran matematika. Selain itu, pembelajaran ini mampu menumbuhkan rasa cinta peserta didik dengan budaya-budaya lokal yang menjadikan kecintaan ini memberikan kompetensi afektif yang positif bagi siswa sebagai wujud nasionalisme. Proses mempraktekkan konsep matematika dalam pembelajaran dengan kearifan budaya lokal biasa disebut etnomatematika. Etnomatematika adalah suatu ilmu yang digunakan untuk memahami bagaimana matematika diadaptasi dari sebuah budaya ${ }^{4}$.

${ }^{3}$ Lebih Lanjut lihat .https://wwwacademia. edu/3854314/Metode_Pembelajaran_yang_cocok_untuk_ Kurikulum_2013.

${ }^{4}$ Marsigit, "Pengembangan Pembelajaran Matematika Berbasis Etnomatematika". Makalab dipresentasikan pada Seminar Nasional Matematika dan Pendidikan Matematika 2016 dengan Tema :
Melalui artikel ini, penulis akan memaparkan bagaimana peran etnomatematika dalam pembelajaran matematika yang diterapkan pada pendekatan saintifik, mengingat pendekatan ini merupakan jiwa dan semangat dari terbentuknya kurikulum 2013.

\section{METODE PENELITIAN}

Metode yang digunakan dalam penelitian ini merupakan penelitian studi kepustakaan (library research). Dalam penelitian jenis ini, dikaji pengetahuan, gagasan, atau temuan yang terdapat di dalam literatur sehingga memberikan informasi teoritis dan ilmiah terkait peran etnomatematika dalam pembelajaran matematika. Data yang dikumpulkan dan dianalisis merupakan data sekunder yang berupa hasil-hasil penelitian seperti buku-buku bacaan ilmiah, jurnal ilmiah, laporan penelitian, situs internet dan lainya yang relevan dengan Ethnomatematika dan pembelajaran matematika pada Kurikulum 2013. selanjutnya, teknik analisis data dalam penelitian meliputi 3 tahapan, pertama, organize yakni mengorganisasikan literatur-literatur yang akan digunakan. Literatur yang digunakan terlebih dahulu di-review agar relevan/sesuai dengan permasalahan. Pada tahapaan ini penulis melakukan pencarian ide, tujuan, dan simpulan dari beberapa literatur dimulai dari membaca abstrak, pendahuluan, metode serta pembahasan serta mengelompokkan literatur berdasarkan kategori-kategori tertentu. Kedua, synthesize yakni menyatukan hasil organisasi literatur menjadi suatu ringkasan agar menjadi satu kesatuan yang padu, dengan mencari keterkaitan antar literatur. Ketiga, identify yakni mengidentifikasi isu-isu kontroversi dalam literatur. Isu kontroversi yang dimaksud adalah isu yang dianggap sangat penting untuk dikupas atau dianalisis, guna mendapatkan suatu tulisan yang menarik untuk dibaca ${ }^{5}$.

Etnomatematika, Matematika dalam Perspektif Sosial dan Budaya, 2016) Hal 1-38

${ }^{5}$ Lebih Lanjut lihat https://www.Researchgate. Net/Publication/304216580_Dinamika_ Perkembangan_Matematika_Abad_Pertengahan_ Hingga_Munculnya_Gerakan_Renaissance_ Implikasinya_Terhadap_Pembelajaran_Matematika_ Di_Sekolah_Implikasinya_Terhadap_Pembelajaran_ Matematika_Di_Sekolah 


\section{PEMBAHASAN}

\section{Ethnomatematika}

Matematikawan Brasil, D’Ambrosio mengatakan Etnomatematika Matematika yang dipraktekkan di antara kelompok budaya diidentifikasi seperti masyarakat nasional suku, kelompok buruh, anak-anak dari kelompok usia tertentu dan kelas profesional ${ }^{6}$. Pendapat lainnya, dikatakan bahwa etnomatematika adalah suatu ilmu yang digunakan untuk memahami bagaimana matematika diadaptasi dari sebuah budaya dan berfungsi untuk mengekspresikan hubungan antara budaya dan matematika ${ }^{7}$. Sehingga dapat dikatakan bahwa etnomatematika merupakan ilmu dalam mengkaji kebudayaan masyarakat, peninggalan sejarah yang terkait dengan matematika dan pembelajaran matematika.

Dalam bidang matematika, etnomatematika masih merupakan kajian yang baru dan berpotensi sangat baik untuk dikembangkan menjadi inovasi pembelajaran kontekstual sekaligus mengenalkan budaya indonesia kepada peserta didik. Sehingga bidang etnomatematika dapat digunakan sebagai pusat proses pembelajaran dan metode pengajaran, walaupun masih relatif baru dalam dunia pendidikan ${ }^{8}$.

Pada umumnya, pembelajaran matematika hanya terfokus pada pembelajaran di dalam kelas. Sehingga dapat diasumsikan, minat dan motivasi siswa dalam belajar matematika sebagaian besar relatif rendah. Hadirnya etnomatematika dalam pembelajaran matematika memberikan nuansa baru bahwa belajar matematika tidak hanya terkungkung didalam kelas tetapi dunia luar dengan mengunjungi atau berinteraksi dengan kebudayaan setempat dapat digunakan sebagai media pembelajaran matematika. Sementara itu, dilihat dari sisi pendekatan pembelajaran, maka

${ }^{6} \mathrm{D}$ 'Ambrosio, U. Ethnomathematics and its place in the history and pedagogy of mathematics. For the Learning of Mathematics, Vol. 5. No.1, 1985, Hal 44-48.

${ }^{7}$ Marsigit, "Pengembangan Pembelajaran Matematika Berbasis Etnomatematika”. Makalab dipresentasikan pada Seminar Nasional Matematika dan Pendidikan Matematika 2016 dengan Tema: Etnomatematika, Matematika dalam Perspektif Sosial dan Budaya, 2016) Hal 1-38

${ }^{8}$ Shirley, L.. Using Ethnomathematics to find Multicultural Mathematical Connection: NCTM, 1995. ethnomatematika selaras dengan pendekatan pembelajaran matematika yang cocok jika diterapkan dalam kurikulum 2013.

\section{Pembelajaran Matematika pada Kurikulum 2013}

Salah satu indikator dari keberhasilan suatu pembelajaran, ketika materi yang disajikan dapat dimengerti dan dipahami oleh sebagian besar peserta didik. Keberhasilan ini tentunya tidak terlepas dari bagaimana cara seorang guru dalam menyampaikan materi melalui berbagai macam metode, model, bahkan pendekatan dalam proses pembelajaran. Dalam kurikulum 2013, pembelajaran matematika bertujuan memfasilitasi peserta didik agar memiliki kemampuan penalaran, pemecahan masalah, komunikasi matematis, koneksi matematis, literasi matematis, dan representasi matematis. Oleh karena itu, sangat diperlukan pendekatan pembelajaran yang mampu mewujudkan minimal salah satu dari kemampuan tersebut.

Ada beberapa pendekatan pembelajaran matematika yang dicocok untuk diterapkan pada kurikulum 2013. berikut lima (5) pendekatan tersebut :

\section{Pendekatan Pembelajaran Problem Based Learning}

Pembelajaran berbasis masalah (PBM) atau Problem-Based Learning (PBL) adalah metode pembelajaran yang bercirikan adanya permasalahan nyata yang tidak terstruktur dengan baik sebagai konteks untuk para peserta didik belajar berfikir kritis dan keterampilan memecahkan masalah dan memperoleh pengetahuan'. Pembelajaran PBL memiliki langkah-langkah sebagai berikut :

a. Penentuan masalah Penentuan masalah dapat dilakukan oleh guru dan para siswa, atau diajukan oleh guru untuk menyesuaikan dengan kompetensi yang akan dicapai.

b. Pemecahan masalah

c. Presentasi hasil kerja kelompok

d. Pada langkah ini setiap kelompok akan mempresentasikan pemecahan terhadap

${ }^{9}$ Lebih Lanjut lihat .https://wwwacademia. edu/3854314/Metode_Pembelajaran_yang_cocok_untuk_ Kurikulum_2013. 
masalah yang ada dilanjutkan dengan diskusi termasuk mendiskusikan materi yang dapat dikembangkan dari permasalahan yang diajukan dan penyelesaian.

e. Pengembangan materi pembelajaran berdasarkan penyelesaian masing-masing kelompok.

\section{Pendekatan Pembelajaran Kooperatif}

Merupakan suatu model pembelajaran yang mengutamakan adanya kelompokkelompok. Setiap siswa yang ada dalam kelompok mempunyai tingkat kemampuan yang berbeda-beda (tinggi, sedang dan rendah) dan jika memungkinkan anggota kelompok berasal dari ras, budaya, suku yang berbeda serta memperhatikan kesetaraan jender. Model pembelajaran kooperatif mengutamakan kerja sama dalam menyelesaikan permasalahan untuk menerapkan pengetahuan dan keterampilan dalam rangka mencapai tujuan pembelajaran ${ }^{10}$.

Secara umum langkah-langkah pembelajaran kooperatif diantaranya :

a. Menyampaikan tujuan dan memotivasi siswa

b. Menyajikan informasi

c. Mengorganisasikan siswa kedalam kelompok belajar

d. Membimbing kelompok belajar

e. Evaluasi

f. Memberikan penghargaan

\section{Pendekatan Berbasis Proyek}

Model pembelajaran berbasis proyek merupakan suatu model pembelajaran yang menyangkut pemusatan pertanyaan dan masalah yang bermakna, pemecahan masalah, pengambilan keputusan, proses pencarian berbagai sumber, pemberian kesempatan kepada anggota untuk bekerja secara kolaborasi, dan menutup dengan presentasi produk nyata ${ }^{11}$. Adapun langkahlangkah dalam pembelajaran berbasis proyek diantaranya

a. Pembukaan

b. Penguatan materi

c. Pembagian kelompok

${ }^{10}$ Lebih Lanjut lihat $h t t p: / / p 4 t k m a t e m a t i k a . o r g /$ downloads/PPP/PPP_Pembelajaran_Kooperatif.pdf.

${ }^{11}$ Lebih lanjut libat di : bttp://wwr.Autodesk.com d. Penugasan kelompok dalam bentuk proyek

e. Empirik

f. Presentasi hasil penugasan dan

g. Refleksi dan evaluasi ${ }^{12}$

\section{Pendekatan Pembelajaran Kontekstual}

Menyatakan bahwa Pendekatan kontekstual atau Contextual Teaching and Learning (CTL) adalah pendekatan pembelajaran yang mengkaitkan antara materi yang dipelajari dengan konteks kehidupan sehari-hari siswa ${ }^{13}$. CTL memiliki tujuh komponen yang dapat dimunculkan dalam implementasi Pembelajaran kontekstual, tujuh komponen tersebut diantaranya
a. Konstrutivisme
b. Bertanya
c. Menemukan
d. Masyarakat Belajar
e. Permodelan
f. Refleksi
g. Penilaian Otentik ${ }^{14}$

\section{Pendekatan Pembelajaran Saintifik}

Pendekatan saintifik (Scientific Approach) atau biasa disebut dengan pendekatan ilmiah merupakan pendekatan pembelajaran yang menjadi dasar munculnya kurikulum 2013. Keilmiahan merujuk pada: (1) adanya fakta, (2) sifat bebas prasangka, (3) sifat objektif, dan (4) adanya analisa ${ }^{15}$. Scientific berarti ilmiah, sehingga dalam pembelajaran apapun, terlebih

${ }^{12}$ Prabowo, A. "Pembelajaran Berbasis Proyek Untuk Meningkatkan Pemahaman Mahasiswa atas Permasalahan Statistika pada Perkuliahan Studi Kasus dan Seminar" Jurnal Kreano. Vol. 3 No. 2, 2012.

${ }^{13}$ Syahbana, A. Peningkatan Kemampuan Berpikir Kritis Matematis Siswa SMP Melalui Pendekatan Contextual Teaching And Learning. Jurnal Edumatica. Vol. 2, No.01, 2012, Hal 45-57.

${ }^{14}$ Depdiknas. Materi Sosialisasi dan Pelatiban Kurikulum Tingkat Satuan Pendidikan (KTSP) SMP. Jakarta: Pusat Kurikulum Depdiknas, 2007

${ }^{15}$ Atsnan, dkk. Penerapan Pendekatan Scientific Dalam Pembelajaran Matematika SMP Kelas VII Materi Bilangan (Pecahan). Makalab dipresentasikan dalam Seminar Nasional Matematika dan Pendidikan Matematika dengan tema " Penguatan Peran Matematika dan Pendidikan Matematika untuk Indonesia yang Lebib Baik" di Jurusan Pendidikan Matematika FMIPA UNY. 9 November 2013. Hal 429-236 
pembelajaran matematika bahwa konsep keilmuan matematika yang akan diberikan dan bangun oleh peserta didik harus berdasarkan pengamatan/ observasi empirik, terukur, selanjutnya mampu memformulasikan hipotesis hingga menguji hipotesis tersebut. Berdasarkan kurikulum 2013, bahwa pendekatan saintifik memiliki 5 langkah pembelajaran diantaranya yaitu: mengamati, menanya, mengumpulkan informasi, mengasosiasi, dan mengkomunikasikan ${ }^{16}$.

\section{Peran Ethnomatematika dalam Pembelajaran Matematika pada Kurikulum 2013}

Pada tulisan sebelumnya, penulis telah membahas beberapa pendekatan pembelajaran matematika yang cocok ketika diterapakan pada kurikulum 2013. Hanya saja pada bagian ini penulis memfokuskan peranan ethnomatematika pada pendekatan pembelajaran saintifik, karena yang telah disampaikan, bahwa pendekatan saintifik merupakan dasar serta merupakan semangat dan jiwa terbentuknya kurikulum 2013.

Implementasi pembelajaran matematika pada kurikulum 2013 lebih menekankan pada metode ilmiah (Scientific Methode). Sehingga melalui metode ilmiah, konsep pengetahuan siswa terkonstruksi berdasarkan fakta ilmiah yang diawali dengan melakukan pengamatan. Sebagaimana yang disampakan Marsigit (2016) mengatakan Fakta atau fenomena merupakan objek keilmuan yang digunakan untuk membangun (Ilmu) Pengetahuan dengan pendekatan Saintifik yang melibatkan unsur logika dan pengalaman. Segala macam kira-kira, khayalan, legenda, atau dongeng dapat berfungsi untuk memperkuat landasan pikiran dan pengalaman. Pendekatan saintifik dapat menjadikan siswa lebih aktif dalam mengkonstruksi pengetahuan dan keterampilannya, juga dapat mendorong siswa untuk melakukan penyelidikan guna menemukan fakta-fakta dari suatu fenomena atau kejadian ${ }^{17}$. Dalam pendekatan saintifik, proses

${ }^{16}$ Kemdikbud. Pengembangan Kurikulum 2013 : Paparan Mendikbud dalam Sosialisasi Kurikulum 2013. Jakarta :Kemdikbud

${ }^{17}$ Efriana, F. " Penerapan Pendekatan Scientific Untuk Meningkatkan Hasil Belajar Siswa Kelas VII MTSn Palu Barat Pada Materi Keliling Dan Luas pembelajaran dimulai dengan mengamati suatu fenomena atau kejadian sebagai sumber belajar, selanjutnya menanya, mengumpulkan informasi, mengasosiasi, dan mengkomunikasikan.

\section{Mengamati dan Menanya}

Disini merupakan bagian awal pembelajaran dimana peserta didik diajak untuk mengamati suatu fenomena. Fenomena disini salah satunya adalah dengan mengamati fenomena alam atau lingkungan. Fenomena ini dapat berupa suatu hal yang berkaitan dengan kehidupan sehari-hari atau sering berinteraksi secara langsung dengan peserta didik. Perlu diketahui, ketika sumber belajar berupa pengamatan dari pengalaman dalam kehidupan, maka etnomatematika memiliki kontribusi dengan menyajikan nilai-nilai budaya setempat sehingga mampu dijadikan sumber belajar dalam mengkonstruksi konsep matematika. Tidak dapat dipungkiri, kesulitan peserta didik dalam memahami konsep matematika dikarenakan dalam pembelajaran selalu diawali dengan objek matematika yang abstrak. Pembelajaran matematika sekolah dilaksanakan dengan menempatkan realitas dan pengalaman siswa sebagai titik awal pembelajaran ${ }^{18}$. Dalam pembelajaran kita dapat mengatakan bahwa konsep matematika abstrak merupakan ilmu matematika formal, sementara konsep matematika yang konkret merupakan ilmu matematika informal.

Keterkaitan antara keduanya memberikan makna bahwa konsep matematika abstrak sesungguhnya terbangun/terkonstruksi dari matematisasi konkret terlebih dahulu. Sehingga keterkaitan ini memunculkan istilah fenomena gunung es (iceberg). Ilmu matematika formal yang nampak dari diri siswa merupakan puncak dari gunung es. Meskipun ilmu abstrak tersebut terlihat sangat sedikit, ilmu tersebut dibangun oleh kaki-kaki gunung es yang sangat besar dan banyak tetapi tidak terlihat. Jika pondasi gunung es rapuh

Daerah Layang-Layang", Jurnal Elektronik Pendidikan Matematika Tadulako. Vol. 2 No.2, 2014, hal 170-181.

${ }^{18}$ Andrijati, N. "Pengembangan Perangkat Pembelajaran Matematika Realistik Dalam Perkuliahan Pengembangan Pembelajaran Matematika Sekolah Dasar di PGSD Tegal". Jurnla Penelitian Pendidikan. Vol. 29, No.2, 2012, Hal 117 -124. 


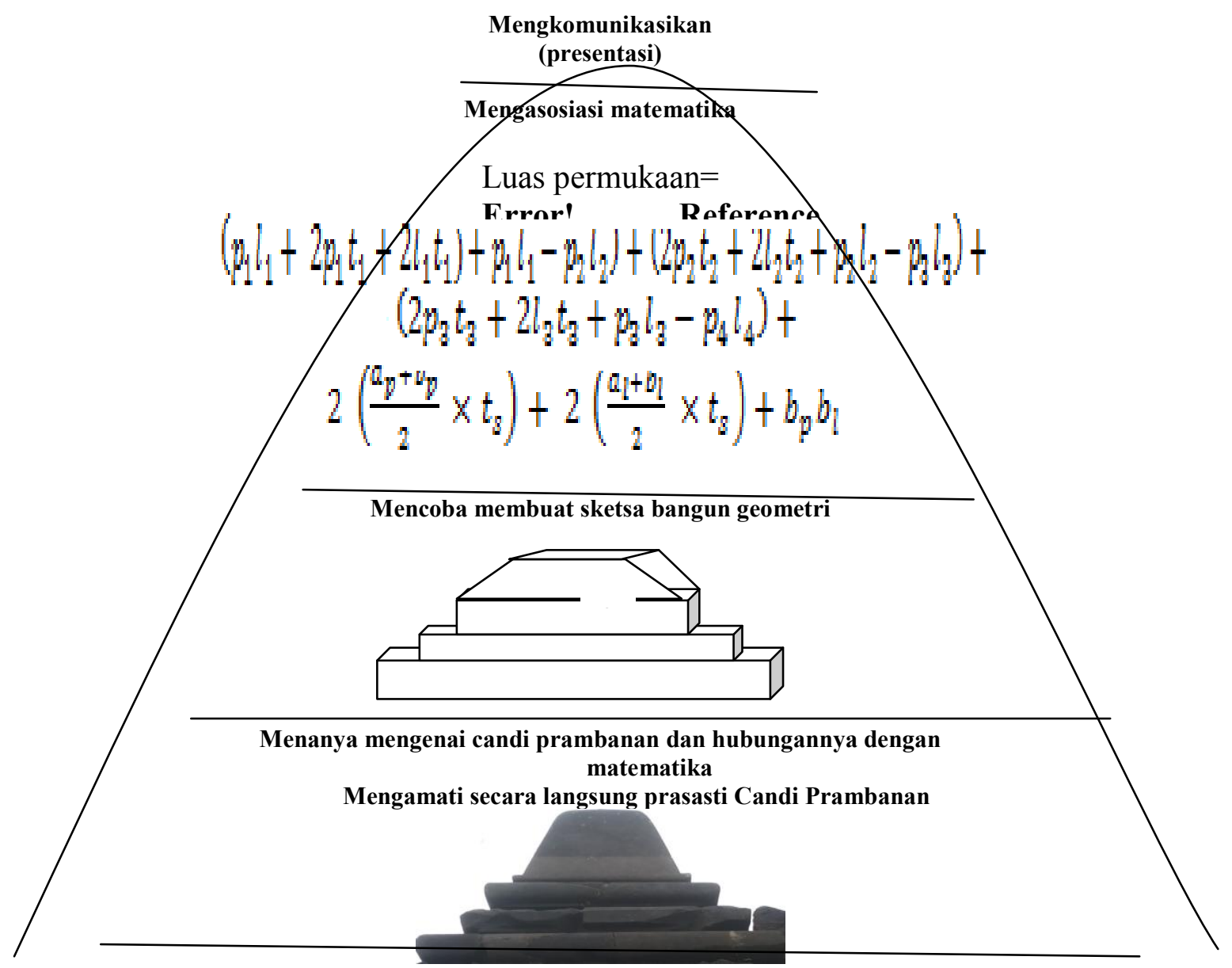

Gambar 1. Contoh sketsa pembelajaran saintifik berbasis etnomatematika ${ }^{20}$

maka puncaknya akan mudah roboh. Begitu pula dengan ilmu matematika yang dibangun oleh siswa. Jika dasar-dasar ilmu matematika informal siswa tidak kokoh maka ilmu formalnya juga akan mudah dilupakan atau hilang ${ }^{19}$. Berdasarkan kegiatan pengamatan, maka peserta didik akan terangsang untuk memikirkan maksud serta keterkaitan apa yang diamati dengan konsep matematika. Disini peran guru harus mampu berusaha menggali memunculkan pertanyaanpertanyaan dari siswa dan mengarahkannya pada solusi dan dapat memunculkan pertanyaan baru sehingga muncul suatu pemikiran yang divergen.

${ }^{19}$ Marsigit, "Pengembangan Pembelajaran Matematika Berbasis Etnomatematika". Makalah dipresentasikan pada Seminar Nasional Matematika dan Pendidikan Matematika 2016 dengan Tema : Etnomatematika, Matematika dalam Perspektif Sosial dan Budaya, 2016) Hal 1-38

\section{Mencoba ${ }^{20}$}

Dalam proses ini peserta didik diajak untuk mengumpulkan informasi dalam matematika berdasarkan hasil pengamatan. Selanjutnya mencoba menungkan hasil pengamatan tersebut kedalam sebuah konsep matematis sehingga lebih mudah untuk dipahami. Penuangannya dari proses ini dapat berupa teorema, sifat atau konsep yang terkait dengan pokok materi yang sedang dibahas. Informasi yang diperoleh ini selanjutnya diobservasi untuk menjadi dasar langka yang selanjutnya.

${ }^{20}$ Marsigit, "Pengembangan Pembelajaran Matematika Berbasis Etnomatematika". Makalah dipresentasikan pada Seminar Nasional Matematika dan Pendidikan Matematika 2016 dengan Tema: Etnomatematika, Matematika dalam Perspektif Sosial dan Budaya, 2016) Hal 1-38 


\section{Mengasosiasi}

Tahap ini merupakan kelanjutan setelah peserta didik mampu menuangkan hasil pengamatannya kedalam sebuah sifat atau konsep suatu materi. Pada proses ini, peserta didik diharapkan mampu melakukan penalaran sehingga ditemukan rumus, penyelesaian atau kesimpulan dari masalah yang diberikan.

\section{Mengkomunikasikan}

Komunikasi disini diartikan sebagai proses penyampaian hasil yang dituangkan dalam bahasa tulis dan bahasa lisan (presentasi). tahapan ini pun bisa dimaknai sebagai tindakan membentuk jejaring (networking) secara fisik yaitu bekerjasama atau berkolaborasi antar siswa.

Berdasarkan paparan tersebut, maka secara tersirat bahwa peran etnomatematika secara umum dalam pembelajaran saintifik diantaranya :

1. Memperoleh kesempatan untuk melakukan kegiatan penemuan dan penyelidikan polapola untuk menentukan hubungan matematika

2. Mempunyai rasa ingin tahu, keinginan bertanya, kemampuan menyanggah dan kemampuan memperkirakan

3. Tidak hanya menggunakan satu metode saja dalam menylesaikan matematika

4. Menyediakan lingkungan belajar matematika yang merangsang timbulnya persoalan matematika

5. Belajar dalam kelompok dapat melatih kerjasama

6. Menyediakan kegiatan yang menyenangkan

7. Membangun pengertian melalui apa yang mereka ketahui

8. Menciptakan suasana kelas yang mendudukung dan merangsang belajar

9. Memberikan kegiatan yang menantang

10. Berusaha mengenali dan menjelaskan sifatsifat matematika

11. Menghargai penemuan yang diluar perkiraan sebagai hal bermanfaat

12. Berusaha menemukan struktur dan desain matematika $^{21}$

${ }^{21}$ Marsigit, "Pengembangan Pembelajaran Matematika Berbasis Etnomatematika”. Makalab dipresentasikan pada Seminar Nasional Matematika dan Pendidikan Matematika 2016 dengan Tema :
Sedangkan secara khusus penulis sampaikan bahwa peran etnomatematika dalam pembelajaran saintifik meliputi :

1. Menyediakan lingkungan pembelajaran matematika yang biasanya terbatas didalam kelas menjadi pembelajaran diluar kelas, sehingga tercipta movitasi yang positif dan pembelajaran matematika menjadi menyenangkan.

2. konsep dan pengetahuan yang terkonsturksi oleh peserta didik benar-benar nyata berdasarkan lingkungan siswa sendiri

3. Terciptanya rasa menghargai, nasionalisme dan kebanggaan atas peninggalan tradisi, seni dan kebudayaan bangsa.

\section{KESIMPULAN}

Berdasarkan uraian diatas, maka peran etnomatematika dalam penerapan pembelajaran matematika pada kurikulum 2013 bahwa

1. Etnomatematika memfasilitasi peserta didik untuk mampu mengkonstruksi konsep matematika dengan pengetahuan awal yang sudah mereka ketahui karena melalui lingkungan siswa sendiri.

2. Etnomatematika menyediakan lingkungan pembelajaran yang menciptakan motivasi yang baik dan menyenangkan serta bebas dari anggapan bahwa matematika itu menakutkan.

3. Etnomatematika mampu memberikan kompetensi afektif yang berupa terciptanya rasa menghargai, nasionalisme dan kebanggaan atas peninggalan tradisi, seni dan kebudayaan bangsa

4. Etnomatematika mendukung kemampuankemampuan siswa sesuai dengan harapan implementasi pendekatan saintifik.

\section{DAFTAR PUSTAKA}

Alawiyah, F. 2013. Kesiapan Guru Dalam Implementasi Kurikulum 2013. Jurnal Pengkajian (P3D1). 6 (15) : 9-12.

Andrijati, N. 2012. Pengembangan Perangkat Pembelajaran Matematika Realistik Dalam Perkuliahan Pengembangan Pembelajaran Matematika Sekolah Dasar di PGSD Tegal.

Etnomatematika, Matematika dalam Perspektif Sosial dan Budaya, 2016) Hal 1-38 
Jurnla Penelitian Pendidikan. 29 (2) : 117 $-124$.

Atsnan, dkk. 2013. Penerapan Pendekatan Scientific Dalam Pembelajaran Matematika SMP Kelas VII Materi Bilangan (Pecahan). Makalah dipresentasikan dalam Seminar Nasional Matematika dan Pendidikan Matematika dengan tema "Penguatan Peran Matematika dan Pendidikan Matematika untuk Indonesia yang Lebih Baik" di Jurusan Pendidikan Matematika FMIPA UNY. 9 November 2013. Yogyakarta. Indonesia. Hal 429-236

Depdiknas. 2007. Materi Sosialisasi dan Pelatiban Kurikulum Tingkat Satuan Pendidikan (KTSP) SMP. Jakarta: Pusat Kurikulum Depdiknas.

D’Ambrosio, U. (1985). Ethnomathematics and its place in the history and pedagogy of mathematics. For the Learning of Mathematics, 5(1), 44-48.

Efriana, F. 2014. Penerapan Pendekatan Scientific Untuk Meningkatkan Hasil Belajar Siswa Kelas VII MTSn Palu Barat Pada Materi Keliling Dan Luas Daerah Layang-Layang. Jurnal Elektronik Pendidikan Matematika Tadulako. 2 (2) : 170-181.

Kemdikbud. 2013. Pengembangan Kurikulum 2013 : Paparan Mendikbud dalam Sosialisasi Kurikulum 2013. Jakarta :Kemdikbud

Kusaeri, dkk. 2016. Dinamika Perkembangan Matematika Abad Pertengahan Hingga Munculnya Gerakan Renaissance. https: / / www.Researchgate.Net/ Publication/304216580_Dinamika_ Perkembangan_Matematika_Abad_ Pertengahan_Hingga_Munculnya_ Gerakan_Renaissance_Implikasinya_ Terhadap_Pembelajaran_Matematika_ Di_Sekolah_Implikasinya_Terhadap_ Pembelajaran_Matematika_Di_Sekolah. Diakses Tanggal 5 Oktober 2016.
Marsigit. 2013. Berbagai Metode Pembelajaran Yang Cocok Untuk Kurikulum 2013. https://www.academia.edu/3854314/ Metode_Pembelajaran_yang_cocok_untuk_ Kurikulum_2013. Diakses Tanggal 5 Oktober 2016.

. 2016. Pengembangan Pembelajaran Matematika Berbasis Etnomatematika. Makalah dipresentasikan pada Seminar Nasional Matematika dan Pendidikan Matematika 2016 dengan Tema : Etnomatematika, Matematika dalam Perspektif Sosial dan Budaya.16 April 2016. Sumatra Barat. Indonesia. Hal 1-38.

Prabowo, A. 2012. Pembelajaran Berbasis Proyek Untuk Meningkatkan Pemahaman Mahasiswa atas Permasalahan Statistika pada Perkuliahan Studi Kasus dan Seminar. Jurnal Kreano. 3 (2).

Rahayu, dkk. 2008. Pengembangan Instrumen Penilaian Dalam Pendidikan Matematika Realistik Indonesia (PMRI) Di SMPN 17 Palembang. Jurnal Pendidikan Matematika. $2(2): 19-35$.

Shirley, L. 1995. Using Ethnomathematics to find Multicultural Mathematical Connection: NCTM.

Syahbana, A. 2012. Peningkatan Kemampuan Berpikir Kritis Matematis Siswa SMP Melalui Pendekatan Contextual Teaching And Learning. Jurnal Edumatica. 2(01) : 45-57.

Thomas, J.W. 2000. A Review Of Research on Project Based Learning. California: The Autodesk Foundation. Tersedia pada: http://www.Autodesk.com. Diakses pada 5 Oktober 2016.

Widyanti. 2010. Model Pembelajaran Matematika Dengan Pendekatan Kooperatif. bttp:// p4tkmatematika.org/downloads/PPP/PPP_ Pembelajaran_Kooperatif.pdf. Diakses Tanggal 5 Oktober 2016. 